\title{
Explaining the Financial Performance of China's Industrial Enterprises: Beyond the Competition-Ownership Controversy*
}

\author{
Yuk-shing Cheng and Dic Lo
}

\begin{abstract}
Scholarly explanations of the worsening financial performance of Chinese industry over the reform era, particularly the loss-making phenomenon, have coalesced around two rival stories: the "inefficient institutions causing poor financial performance" story and the "increased competition inducing profitability decline" story. This article critically reviews the arguments and empirical substantiation of the two stories, and gives an alternative explanation that takes demand conditions and industrial configurations into the analysis. On this basis, it is argued that the worsening financial performance is a macro as well as micro problem that points to the fundamental contradictions in contemporary Chinese political economy. Some policy implications from this analysis are raised in the concluding section.
\end{abstract}

Chinese prime minister Zhu Rongji pledged to solve the problem of loss-making by the country's state-owned industrial enterprises within a period of three years when he took up office in March 1998. The fact that he put this as the number one task of his new administration clearly reflects the severity of the problem. A quick glance at the relevant statistics suffices to impress that this is the case. As is indicated in Figure 1 , by 1997 , total losses as a ratio of the net output of all industrial enterprises was more than three times the ratio in 1980, increasing from 2.43 to 8.24 per cent. The increase in the incidence of loss-making is even more alarming: almost one-fourth of all enterprises suffered from losses by 1997 , compared with the ratio of one-eighth in 1980. Table 1 further indicates that loss-making enterprises, whilst accounting for 25-30 per cent of the productive inputs of Chinese industry, turn out only 10 per cent of total output. And amid keeping idle their productive inputs, loss-making enterprises still have to pay for the amount of wages and staff welfare costs commensurable to their input scales. ${ }^{1}$

* The draft of this article was completed during Yuk-shing Cheng's research visit to the School of Oriental and African Studies, University of London. The paper has been subsequently presented at conferences in Cambridge and Beijing. The authors wish particularly to thank Thomas M.H. Chan for his comments on an earlier version.

1. Figures cover all township and above independently accounting industrial enterprises (TAIAIEs). It is for these enterprises that China's statistical authorities have published consistent data of financial performance, and economic and technical data. The main data series analysed in this article include those of output and losses. The authorities have published aggregate data of net output value for all TAIAIEs for 1980-92 and those of industrial value-added for 1992-97. The same applies to SOEs at this level. For the disaggregated, sector-level output data, what are available are net output data for all TAIAIEs for 1980 and 1984-92 and industrial value-added data for 1992-97. Much less is available for SOEs by industrial sectors: only net output data for 1991 and industrial value-added data for 1992-97. As for losses, there are aggregate data for TAIAIEs and SOEs for 1980-97, as well as 
Figure 1: The Incidence and Scale of Loss-Making, 1980-1997

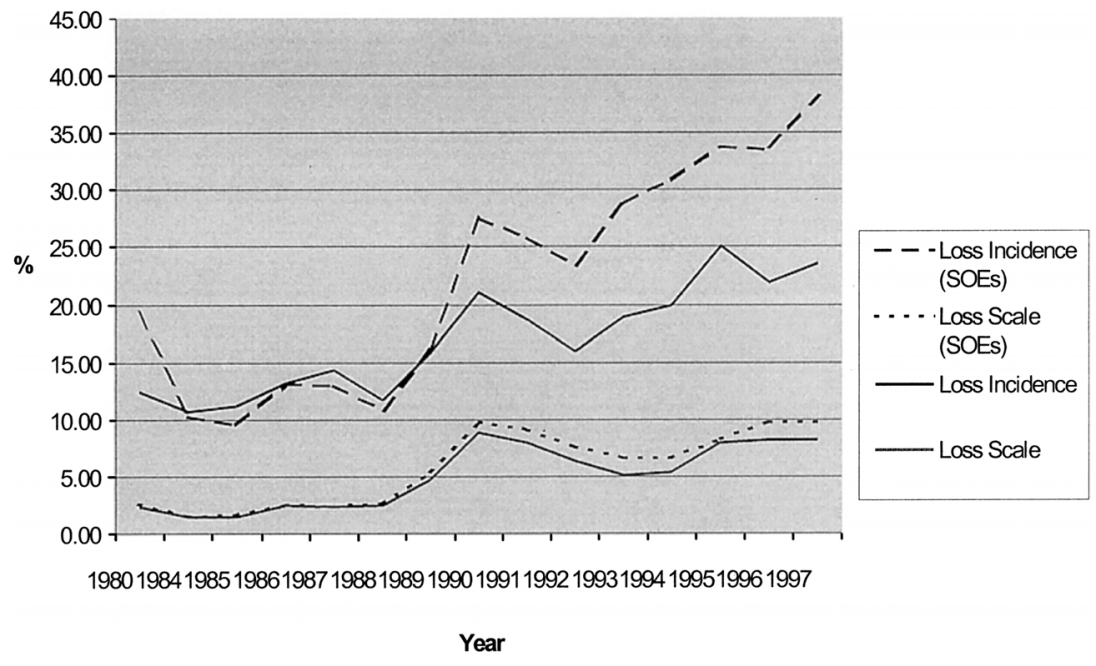

Sources:

State Statistical Bureau, Zhongguo tongji nianjian (China Statistical Yearbook) and Zhongguo tongji zhaiyo (China Statistical Abstract) (Beijing: Zhongguo tongji chubanshe), various issues.

The deteriorating financial performance has thus become a serious policy concern. It is likely to damage the developmental potentials of enterprises, and to dampen the incentive to invest in technical renovation and upgrading for Chinese industry as a whole. These, in turn, will put Chinese industry in a disadvantageous position in the face of market opening and globalized competition. More immediately, against the background of East Asia's financial and economic crisis in the closing years of the century, the deteriorating financial performance of Chinese industry has given rise to the speculation as to whether a similar crisis will occur in the country. For, as is well known in the relevant literature, an influential explanation of the East Asian crisis has it that the crisis stemmed mainly from accumulated problems in the real economy which dragged the financial sector and thereby the macroeconomic conditions into trouble, thus providing room for speculative attacks on the currencies and domestic assets. In the case of China, diagnoses of the economic conditions in this spirit were in vogue among Western media, consultant companies and economists. It was asserted that, because of

\footnotetext{
footnote continued

sector-level data for all TAIAIEs for 1986-92 and 1995 and those for SOEs for 1986-91 and 1995. The 1995 data are from the Third Industrial Census, and hence are the most comprehensive to date. Data about loss incidences are slightly richer than those of the scale of losses as described above. The analysis throughout focuses on data at the level of TAIAIEs, unless indicated otherwise. Since 1998, the authorities have ceased to publish the data for TAIAIEs but have instead published the data for "all state-owned industrial enterprises plus above-scale non-state-owned industrial enterprises" (quanbu gиоуои ji guimoyishang feiguoyou gongye qiye) which account for a major part of the output of all TAIAIEs.
} 
Table 1: Profile of Loss-Making Industrial Enterprises, 1995

\begin{tabular}{|c|c|c|c|c|}
\hline & (a) All TAIAIEs & $\begin{array}{l}\text { (b) All Loss- } \\
\text { making TAIAIEs }\end{array}$ & $\begin{array}{c}(b) /(a) \\
(\%)\end{array}$ & $\begin{array}{l}(b)-(a) \\
(\% \text { points })\end{array}$ \\
\hline Number of enterprises & 510,381 & 127,920 & 25.06 & - \\
\hline Total capital (million yuan) & $2,155,288$ & 580,829 & 26.95 & - \\
\hline Foreign funds (million yuan) & 309,626 & 131,099 & 42.34 & - \\
\hline Year-end net value of fixed assets (million yuan) & $3,228,709$ & 873,146 & 27.04 & - \\
\hline Total wage bills and staff welfare costs (million yuan) & 512,268 & 120,714 & 23.56 & - \\
\hline Year-end liability-asset ratio $(\%)$ & 65.31 & 76.05 & - & 10.74 \\
\hline Year-end inventory-to-total asset ratio (\%) & 16.76 & 16.17 & - & -0.59 \\
\hline Export-to-gross output ratio $(\%)$ & 14.18 & 16.82 & - & 2.64 \\
\hline Pre-tax profit rate $(\%)$ & 8.29 & -5.01 & - & -13.30 \\
\hline Ratio of payments for retired staff to total wage bills and welfare costs (\%) & 14.68 & 17.08 & - & 2.39 \\
\hline Ratio of retired staff to total employment $(\%)$ & 16.66 & 20.62 & - & 3.96 \\
\hline
\end{tabular}

Republic of China in 1995) (Beijing: Zhongguo tongji chubanshe, 1997), Vol. 1, pp. 46-53, 198-203. 
massive non-performing loans caused precisely by the deteriorating financial performance of industrial enterprises, China's state banks were technically insolvent and the economy was on the verge of an East Asian-type crisis. It turned out that this is a gross exaggeration. Nevertheless, the assertion does touch on the serious consequences of the deteriorating enterprise financial performance for China's economy as a whole.

Hitherto, scholarly explanations of the loss-making phenomenon have coalesced around two, essentially rival stories, namely the "inefficient institutions causing poor financial performance" story that dismisses state ownership as by nature incorrigible; and the "increased competition inducing profitability decline" story about the necessary price for constructing a competitive, market-regulated economy. ${ }^{2}$ The unambiguous policy conclusion of the former story is that China's state leadership should embrace mass privatization if the problem of loss-making, and that of the alleged maldevelopment of the Chinese economy in general, is to be resolved. ${ }^{3}$ An obvious difficulty with this story, however, is that the problem of declining financial performance has in fact occurred in all ownership sectors of Chinese industry. This implies that an ownershipcentred explanation of the observed problem is flawed, and could even be misleading, unless one is prepared to argue that the Chinese economy as a whole has performed badly during the reform era.

The alternative, competition-centred explanation emphasizes the erosion of industrial profitability caused mainly by the massive entry of non-state firms. ${ }^{4}$ This appears to be consistent with the observed declining

2. There are of course other explanations for the loss-making phenomenon of Chinese industrial enterprises. Terry Sicular, for instance, contends that it might just be an accounting artifact. Her argument is that SOEs may choose to report losses in order to obtain subsidies from the state, even though they are actually making profits (T. Sicular, "Zhongguo de guoyou qiye weishenme kuisun?" ("Why do Chinese state-owned enterprises make losses"), Jingji yanjiu (Economic Research Journal), No.4 (1995), pp. 21-28). The existence of this kind of strategic behaviour cannot be excluded. However, Chinese researchers and officials often observe the contrary: that is, many enterprises that report positive profits are actually making losses. Qian kui (hidden losses) are widely believed to have occurred in up to one-third of all SOEs (Wu Jinglian, Guoyou jingji de zhanlüexing chongzu (Strategic Restructuring of the State-Owned Economy) (Beijing: Zhongguo fazhan chubanshe, 1998), p.2). This article does not deal with the problem of how many enterprises are over-reporting their profits (or losses) and how many under-reporting. It uses data at the aggregate level or at industrial sector level, assuming that, on balance, they truly reflect the trend of changes.

3. Y. Huang, W.T. Woo and R. Duncan, "Understanding the decline of China's state sector," MOCT-MOST: Economic Policy in Transitional Economies, Vol.9 (1999), pp. 1-15. Y. Cao, G. Fan and W.T. Woo, "Chinese economic reforms: past successes and future challenges," in W.T. Woo, S. Parker and J.D. Sachs (eds.), Economies in Transition: Comparing Asia and Eastern Europe (Cambridge, MA: MIT Press, 1997). G. Fan and W.T. Woo, "State enterprise reform as a source of macroeconomic instability: the case of China," Asian Economic Journal, Vol.10 (1996), pp. 207-224. N.R. Lardy, China's Unfinished Economic Revolution (Washington, DC: Brookings Institution Press, 1998). F. Perkins, "The costs of China's state-owned enterprises," MOCT-MOST: Economic Policy in Transitional Economies, Vol.9 (1999), pp. 17-33.

4. R.F. Ash and L. He, "Loss-making and the financial performance of China's industrial enterprises: data from the new accounting and statistical system," Journal of Contemporary China, Vol.7 (1998), pp. 5-20. G.H. Jefferson and T.G. Rawski, "How industrial reform worked in China: the role of innovation, competition, and property rights," Proceedings of the World Bank Annual Conference on Development Economics 1994 (1995), pp. 129-156. G.H. Jefferson, T.G. Rawski, L. Wang and Y. Zheng, "Ownership, productivity change, and financial performance in Chinese industry," Journal of Comparative Economics, Vol. 28 
financial performance across-the-board. Its further proposition that the nexus of increased competition cum profitability decline has not impeded, but rather has contributed to, the improvement in productivity of the Chinese economy appears to be consistent with the rapid and sustained economic growth over the past two decades. Nevertheless, as far as the explanation of the loss-making phenomenon is concerned, this story is also not free of difficulty. It predicts that, when profitability declines as a result of the entries of more firms, the incidence and scale of lossmaking must go up, that is, the two trends ought to be moving in opposite directions. However, it can be observed that, for a good part of the reform era, there was a trend of falling industrial profit rates alongside that of falling incidence and scale of losses. It is also observable that, moving down to the more disaggregated level of individual industrial sectors and especially in the 1980s, there is no clear correspondence either between the entry of non-state firms and the decline in sectoral profit rates, or between the profitability decline and the sectoral shares of total losses. These suggest that the nature of competition in Chinese industry needs to be explicitly analysed, and that there are likely to be some other, more fundamental factors which condition the relationship between competition and loss-making.

In this connection, a number of sector-level studies that have emerged recently offer useful insights for further investigating into the topic. In a study of several manufacturing industries, Peter Nolan draws attention to a spectacular development in the 1990s: the general trend of rapid increase in the degree of concentration in the industries, which reverses the trend of the 1980s. The rising concentration may imply a process of redistribution of profits among firms, a phenomenon that the competitioncentred story has ignored. Similar findings have been obtained by the comprehensive study of six industrial branches by Jiang Xiaojuan and associated writers, and the detailed analysis of China's broad machinery and electronics sector by Dic Lo and Thomas Chan - both concluding that the increase in concentration has in fact largely improved the efficiency and competitiveness of the industries concerned via economies of scale. The latter two studies also both point out that the increase in concentration has proceeded in conjunction with the slowdown in demand expansion. These findings give rise to the proposition raised by Zhang Jun that the relationship between competition and loss-making is contingent on the extent of the market, that is, the pace of demand expansion. Unlike the 1980s, when increased competition and profitability decline did not lead to a worsening of loss-making because of the general expansion of the market, the slowdown in demand expan-

footnote continued

(2000), pp. 786-813. B. Naughton, Growing Out of the Plan: Chinese Economic Reform 1978-1993 (Cambridge: Cambridge University Press, 1995). M. Raiser, "Evaluating Chinese industrial reforms: SOEs between output growth and profit decline," Asian Economic Journal, Vol.11 (1997), pp. 299-323. X. Wang, China's Price and Enterprise Reform (Basingstoke: Macmillan Press; New York: St. Martin's Press, 1998). 
sion and the increased market concentration in the 1990s have resulted in a massive rise in the incidence and scale of loss-making. ${ }^{5}$

The limitation of these studies, however, is that the concerned propositions are essentially hypotheses in nature. Their empirical backing has been rather limited, supported either by aggregate data or by analyses of some specific industrial sectors. In contrast, on the basis of disaggregate data of wide coverage and by probing into previously ignored aggregate variables, this article seeks to offer a far more comprehensive and coherent analysis of the loss-making phenomenon. The ambition is explicitly to take into consideration the evolution of the sector-level configurations, the demand-side conditions and the underlying institutional factors, which combine to determine the nature of competition in Chinese industry and the resulting loss-making phenomenon.

The article is organized in four sections. The first takes on the "inefficient institutions causing poor financial performance" story. It analyses the pattern of loss-making at both the aggregate and sector levels, and the evolution of the pattern in relation to the role of government policies and state-owned enterprises. The second section turns to the "increased competition inducing profitability decline" story. It examines the relationship between profit rates and the loss-making phenomenon, again at both the aggregate and sector levels. The following section incorporates the considerations of demand-side conditions and industrial configurations into the analysis of the relationship between competition and loss-making. Finally, there are some conclusions and suggested directions for future research.

\section{Government Policies, Institutions and Loss-Making}

The "inefficient institutions causing poor financial performance" story encompasses a range of arguments that are diverse in nature. Typical of all these arguments, however, is the alleged asymmetry between the decision-making autonomy granted to state-owned enterprises (SOEs) and the responsibility which they have assumed. The flaw of China's economic reform is thus considered to be the delay in ownership reform. ${ }^{6}$

5. P. Nolan, "Large firms and industrial reform in former planned economies: the case of China," Cambridge Journal of Economics, Vol.20 (1996), pp. 1-29. Jiang Xiaojuan, "Tizhi zhuanggui yu chanye fazhan: xiangguanxing, heyixing, yiji dui zhuanggui lilun de yiyi" ("Systemic transition and industrial development: correlation, satisfaction, and the implications for the theory of transition"), Jingji yanjiu, No. 1 (1999), pp. 35-44. D. Lo and T.M.H. Chan, "Machinery and China's nexus of foreign trade and economic growth," Journal of International Development, Vol.10 (1998), pp. 733-749. J. Zhang, "Market size, scale economies and loss-making in China's post-reform state manufacturing industry," unpublished paper, London School of Economics and Fudan University, 1998. Apart from these studies, Chinese economists have also offered some analyses of the causes of enterprise losses at the sector or provincial levels. One example is Fang Weizhong and Wu Jiajun (eds.), Gongye qiye kuisun diaocha yanjiu (The Losses of Industrial Enterprises: Survey and Research) (Beijing: Jingji guanli chubanshe, 1989). The analyses in this book cover the period 1978-87. A more recent book that extends its analyses to the 1990s is Zheng Haihang (ed.), Guoyou qiye kuisun yanjiu (A Study on the Losses of State-Owned Enterprises) (Beijing: Jingji guanli chubanshe, 1998).

6. Huang, Woo and Duncan, "Understanding the decline." 
Nicholas Lardy claims that the high liability-to-asset ratio of enterprises, which as shown in Table 1 is especially pronounced among loss-making enterprises, indicates that many of them are "valuesubtracting." On the face of it, this judgement is dubious. It is of course well known that the burden of interest payments arising from the high level of indebtedness has been a major cause of loss-making. But this does not imply that the cause of heavy indebtedness must be within the enterprises themselves. It could well be caused by factors beyond their control, such as the underdevelopment of the capital market, the fiscal difficulty of the state and hence its policy of undercapitalizing SOEs, or the underdevelopment of the social welfare system and hence the responsibility for enterprises in job security protection and welfare provision. This last point is particularly worth noting, for a further argument from the story is that excessive expansion in labour compensation forms another major cause of loss-making. It is apparent that this argument simply disregards the value of job security protection and welfare provision. Loss-making enterprises could conceivably have performed better in financial terms if not being burdened by the substantially higher-thanaverage ratio of retired staff to employment and ratio of payments for retired staff to total wage bills and welfare costs. But that better performance would in no sense imply an improvement in efficiency. ${ }^{7}$

Whatever the precise nature of its arguments, at the level of empirical analysis, the validity of the ownership-centred story must hinge on the alleged weaker financial performance of SOEs vis-à-vis non-SOEs. Moreover, to argue that SOEs are by nature incorrigible, it must further show that the weaker performance has persisted or even worsened over time. Both of these, however, are not borne out by the available evidence. Table 2 gives the relevant statistics. It is true that SOEs have exhibited a higher incidence and scale of loss-making than non-SOEs. But the actual number of loss-making SOEs has been in the range of one-fifth to one-third of non-SOEs. And the amount of losses incurred by SOEs is 52 per cent of the total in 1997, meaning that it is only slightly larger than that incurred by non-SOEs. More important, the relative performance of SOEs far from deteriorated over the reform era. Its proportion of the total

7. Lardy, China's Unfinished Economic Revolution (p. 49) asserts: “Although official data show wage growth in the state sector lagging behind the growth of labor productivity between 1978 and 1990, these data appear to understate the growth of total compensation, that is, wages plus various subsidies and in-kind benefits. The growth of total compensation has outstripped the growth of labor productivity, contributing to a decline in profitability. Since 1990 this trend has worsened." But, even if this assertion is accepted, it is still unclear as to whether the growth is excessive because it says nothing about the levels. A better approach would be comparing the ratio of total compensation to net output between SOEs and non-SOEs. In 1995, for example, whilst the per worker output of SOEs is almost identical to the average of all ownership sectors, the ratio of total wage bills (including bonus) to net output for SOEs is 3 percentage points higher than average. The difference increases to 6 percentage points if payments for retired staff and welfare costs are included. These figures thus seem to confirm that labour compensation in SOEs is excessive. Nevertheless, it should be noted that even in the case of total wage bills a substantial part is used to pay for surplus labour which, reported to be as high as $20 \%$ of total employment, is more a liability than an asset for SOEs. Deducting (say) $10 \%$ from the total wage bills of SOEs, the ratio to net output would then be on a par with that of average. 
Table 2: SOEs' Shares of Total Losses and the Number of Loss-Making TAIAIEs, 1980-1997

\begin{tabular}{|c|c|c|c|c|c|c|}
\hline & $\begin{array}{l}\text { Number of } \\
\text { loss-making } \\
\text { SOEs }\end{array}$ & $\begin{array}{c}\text { As proportion of } \\
\text { the number of all } \\
\text { SOEs }(\%)\end{array}$ & $\begin{array}{c}\text { As proportion of } \\
\text { all loss-making } \\
\text { TAIAIEs }(\%)\end{array}$ & $\begin{array}{l}\text { Losses of loss- } \\
\text { making SOEs } \\
\text { (million yuan) }\end{array}$ & $\begin{array}{l}\text { As proportion } \\
\text { of the NVIO of } \\
\text { all SOES (\%) }\end{array}$ & $\begin{array}{l}\text { As proportion of } \\
\text { all loss-making } \\
\text { TAIAIEs (\%) }\end{array}$ \\
\hline 1980 & 12,034 & 19.20 & 29.74 & 3,430 & 2.63 & 88.38 \\
\hline 1984 & 11,969 & 18.97 & 28.99 & 2,661 & 1.54 & 77.72 \\
\hline 1985 & 6,749 & 9.59 & 16.71 & 3,244 & 1.59 & 80.10 \\
\hline 1986 & 9,221 & 13.08 & 16.60 & 5,449 & 2.50 & 75.24 \\
\hline 1987 & 9,459 & 12.99 & 15.74 & 6,104 & 2.41 & 72.08 \\
\hline 1988 & 7,912 & 10.91 & 16.12 & 8,192 & 2.67 & 76.87 \\
\hline 1989 & 11,785 & 16.03 & 17.66 & 18,019 & 5.21 & 76.99 \\
\hline 1990 & 20,603 & 27.55 & 23.44 & 34,876 & 9.77 & 76.87 \\
\hline 1991 & 19,443 & 25.84 & 24.78 & 36,700 & 9.13 & 77.18 \\
\hline 1992 & 17,299 & 23.36 & 26.65 & 36,927 & 7.62 & 78.73 \\
\hline 1993 & 23,209 & 28.80 & 26.76 & 45,264 & 6.66 & 70.85 \\
\hline 1994 & 24,637 & 30.90 & 26.49 & 48,259 & 6.55 & 62.47 \\
\hline 1995 & 29,668 & 33.75 & 23.19 & 63,957 & 8.25 & 53.36 \\
\hline 1996 & 29,196 & 33.57 & 26.23 & 79,068 & 9.70 & 55.24 \\
\hline 1997 & 28,433 & 38.22 & 25.70 & 83,095 & 9.69 & 52.36 \\
\hline \multicolumn{7}{|l|}{$\begin{array}{c}\text { Note: } \\
\text { NV }\end{array}$} \\
\hline \multicolumn{7}{|c|}{$\begin{array}{l}\text { Sources: } \\
\text { State Statistical Bureau, Zhonghua renmin gongheguo } 1995 \text { nian disanci quanguo gongye pucha ziliao huibian (Data of the Third Industria } \\
\text { Census of the People's Republic of China in 1995) (Beijing: Zhongguo tongji chubanshe, 1997), Vol. 1, pp. 46-53; State Statistical Bureau } \\
\text { Zhongguo gongye jingji tongji nianjian } 1998 \text { (China Industrial Economic Statistical Yearbook 1998) (Beijing: Zhongguo tongji chubanshe, 1999), } \\
\text { p. 76; Editorial Board, Zhongguo jingji nianjian } 1998 \text { (China Economic Yearbook 1998) (Beijing: Zhongguo jingji guanli chubanshe, 1999), pp } \\
\text { 906-907; Dic Lo, "Reappraising the performance of China's state-owned industrial enterprises, 1980-96," Cambridge Journal of Economics, Vol } \\
23 \text { (1999), pp. 693-718. }\end{array}$} \\
\hline
\end{tabular}

23 (1999), pp. 693-718. 
number of loss-making enterprises in 1997 is four percentage points less than that in 1980, and for all the years in between the proportion is even smaller. In terms of SOEs' share of total losses, there is a spectacular decrease by 36 percentage points between 1980 and 1997. This implies non-SOEs have accounted for a steadily increasing share of total losses. In other words, even with SOEs eliminated (privatized), the problem of loss-making in Chinese industry would still remain very serious. ${ }^{8}$

It is, of course, important to go beyond simply engaging the ownership-centred story as it stands to investigate the precise role of institutions and government policies in the loss-making phenomenon. Relevant statistical data at the disaggregated, industrial sector-level should be examined. Table 3 shows the distribution of total losses among industrial sectors in the years 1986, 1990 and 1995, together with the figures of what could be called the output-adjusted loss index, that is the loss-to-output ratio of a sector divided by the loss-to-output ratio of Chinese industry as a whole, which is used to indicate whether a particular sector has performed more badly than the average of Chinese industry.

Three observations can be made from the table. First, the lion's share of total losses has been highly concentrated in the three energy sectors of coal mining (code 01), petroleum extraction (02) and electricity supply (35) plus ten manufacturing industries, namely, food processing (07-08), beverage processing (09), textile (11), chemicals (20), building materials (25), ferrous metals smelting (26), machinery (29-30), transport equipment (31), electrical equipment (32) and electronics (33). These industrial sectors combine to account for 83 per cent of total losses in 1986, 80 per cent in 1990 and 72 per cent in 1995. The loss-making problem is largely a problem of these industries, which will therefore be on the focus of the analysis below.

Secondly, the three energy industries account for a disproportionately large share of at least 30 per cent of total losses up to 1990, but not in 1995 where the share falls to around 10 per cent. These changes confirm the well-known story about the artificial suppression of the output prices of a range of upstream extraction industries by government policy under the dual-track pricing system of the 1980s, and the ceasing of such controls after the completion of price reform in the early 1990s. Conversely, the continuously serious loss-making phenomenon in the 1990s could not be explained in any large measure by this government policy.

Thirdly, the main loss-makers in the 1990s are exactly the ten manufacturing industries indicated above, and they in fact have persistently made heavy losses since 1986. Their combined share of total losses

8. In terms of the output-adjusted loss index, i.e., the loss-to-output ratio of SOEs divided by that of all enterprises, the value ranges between 1.08 and 1.10 in the years from 1980 to 1990, falling to 0.99 in 1995 and rebounding to 1.13 in 1997 (we use net output figures as the denominator for 1980-90 and value-added figures for 1995 and 1997). There does not appear to exist a clear trend of deteriorating performance of SOEs relative to non-SOEs in this regard. The fact that the value of the index has exceeded one by $10 \%$ or so in most of the years concerned could be viewed in the same light as our discussion on SOEs' slightly higher-than-average ratio of total wage bills to net output (see n. 7). 
Table 3: Output-Adjusted Loss Indices by Industrial Sectors, 1986, 1990, 1995

\begin{tabular}{|c|c|c|c|c|c|c|c|c|c|}
\hline & $\begin{array}{l}1986 \\
\text { (a) Sector } \\
\text { share in } \\
\text { NVIO (\%) }\end{array}$ & $\begin{array}{l}\text { (b) Sector } \\
\text { share in } \\
\text { LoLEs (\%) }\end{array}$ & $(b) /(a)$ & $\begin{array}{l}1990 \\
\text { (a) Sector } \\
\text { share in } \\
\text { NVIO (\%) }\end{array}$ & $\begin{array}{l}\text { (b) Sector } \\
\text { share in } \\
\text { LoLEs }(\%)\end{array}$ & $(b) /(a)$ & $\begin{array}{l}1995 \\
\text { (a) Sector } \\
\text { share in } \\
\text { NVIO (\%) }\end{array}$ & $\begin{array}{l}\text { (b) Sector } \\
\text { share in } \\
\text { LoLEs (\%) }\end{array}$ & $(b) /(a)$ \\
\hline All industries (40 in total) & 100.00 & 100.00 & 1.00 & 100.00 & 100.00 & 1.00 & 100.00 & 100.00 & 1.00 \\
\hline 01 Coal mining \& processing & 3.27 & 30.63 & 9.35 & 3.10 & 16.27 & 5.24 & 3.02 & 2.22 & 0.74 \\
\hline $\begin{array}{l}02 \text { Petroleum \& natural gas } \\
\text { extraction }\end{array}$ & 4.28 & 0.25 & 0.06 & 4.00 & 10.45 & 2.61 & 4.79 & 1.24 & 0.26 \\
\hline $\begin{array}{l}03 \text { Ferrous metals mining \& } \\
\text { dressing }\end{array}$ & 0.28 & 0.17 & 0.59 & 0.25 & 0.12 & 0.49 & 0.23 & 0.33 & 1.41 \\
\hline $\begin{array}{l}04 \text { Non-ferrous metals mining \& } \\
\text { dressing }\end{array}$ & 0.60 & 1.41 & 2.34 & 0.73 & 0.59 & 0.80 & 0.65 & 0.57 & 0.88 \\
\hline $\begin{array}{l}05 \text { Building materials \& other non- } \\
\text { metal minerals mining \& dressing }\end{array}$ & 0.62 & 1.10 & 1.78 & 0.65 & 0.37 & 0.57 & 0.85 & 0.66 & 0.77 \\
\hline $\begin{array}{l}06 \text { Logging and transport of timber } \\
\text { and bamboo }\end{array}$ & 1.20 & 0.58 & 0.48 & 1.04 & 0.77 & 0.74 & 0.59 & 0.29 & 0.49 \\
\hline $\begin{array}{l}07 \text { Food manufacturing } \& \\
08 \text { processing }\end{array}$ & 3.77 & 6.35 & 1.69 & 3.94 & 6.19 & 1.57 & 4.92 & 7.72 & 1.57 \\
\hline 09 Beverage manufacturing & 1.78 & 1.99 & 1.12 & 2.27 & 2.86 & 1.26 & 2.47 & 2.85 & 1.15 \\
\hline 10 Tobacco processing & 4.70 & 0.40 & 0.09 & 5.84 & 1.98 & 0.34 & 4.17 & 0.40 & 0.10 \\
\hline 11 Textile & 9.54 & 5.61 & 0.59 & 9.67 & 10.21 & 1.06 & 6.49 & 12.00 & 1.85 \\
\hline 12 Garments \& other fibre products & 1.77 & 1.80 & 1.01 & 1.98 & 1.06 & 0.53 & 2.50 & 2.48 & 0.99 \\
\hline $\begin{array}{l}13 \text { Leather, furs, down \& related } \\
\text { products }\end{array}$ & 0.87 & 0.61 & 0.69 & 0.89 & 1.35 & 1.52 & 1.53 & 1.87 & 1.22 \\
\hline
\end{tabular}


14 Timber processing, bamboo, cane, palm \& related products

15 Furniture manufacturing

16 Paper making \& paper products

17 Printing \& record medium production

18 Cultural, educational \& sports goods

19 Petroleum refining, coking \& coal products

20 Raw chemical materials \& chemical products

21 Medical \& pharmaceutical products

22 Chemical fibre

23 Rubber products

24 Plastic products

25 Building materials \& other nonmetal mineral products

26 Ferrous metals smelting \& pressing

27 Non-ferrous metals smelting \& pressing

28 Metal products

29 General \& special purpose

30 machinery

31 Transport equipment

\begin{tabular}{|c|c|c|c|c|c|c|c|}
\hline 0.61 & 0.66 & 1.08 & 0.47 & 1.03 & 2.19 & 0.65 & 1.24 \\
\hline 0.53 & 0.44 & 0.83 & 0.43 & 0.53 & 1.24 & 0.41 & 0.49 \\
\hline 1.70 & 0.95 & 0.56 & 1.83 & 1.83 & 1.00 & 1.60 & 1.51 \\
\hline 1.02 & 0.25 & 0.24 & 0.97 & 0.25 & 0.26 & 0.81 & 0.95 \\
\hline 0.52 & 0.15 & 0.29 & 0.50 & 0.25 & 0.50 & 0.64 & 0.48 \\
\hline 4.26 & 1.71 & 0.40 & 2.58 & 1.68 & 0.65 & 3.14 & 0.53 \\
\hline 6.04 & 11.35 & 1.88 & 7.76 & 4.28 & 0.55 & 5.94 & 4.92 \\
\hline 1.43 & 0.32 & 0.22 & 1.84 & 0.84 & 0.46 & 1.93 & 1.78 \\
\hline 1.09 & 0.17 & 0.15 & 1.51 & 0.25 & 0.17 & 1.19 & 1.07 \\
\hline 1.60 & 0.51 & 0.32 & 1.51 & 0.66 & 0.44 & 0.97 & 0.05 \\
\hline 1.39 & 1.38 & 0.99 & 1.63 & 1.36 & 0.84 & 1.59 & 0.13 \\
\hline 6.62 & 5.37 & 0.81 & 5.38 & 6.01 & 1.12 & 5.80 & 8.37 \\
\hline 6.49 & 0.83 & 0.13 & 6.17 & 2.97 & 0.48 & 6.28 & 4.54 \\
\hline 1.73 & 0.72 & 0.42 & 1.93 & 1.16 & 0.60 & 1.95 & 1.66 \\
\hline 2.90 & 1.38 & 0.48 & 2.77 & 1.51 & 0.54 & 2.75 & 3.42 \\
\hline 11.38 & 9.02 & 0.79 & 9.50 & 10.20 & 1.07 & 7.89 & 7.88 \\
\hline 3.39 & 2.62 & 0.77 & 3.68 & 2.52 & 0.68 & 5.58 & 5.58 \\
\hline
\end{tabular}


Table 3: Continued

\begin{tabular}{|c|c|c|c|c|c|c|c|c|c|}
\hline & $\begin{array}{c}1986 \\
\text { (a) Sector } \\
\text { share in } \\
\text { NVIO (\%) }\end{array}$ & $\begin{array}{l}\text { (b) Sector } \\
\text { share in } \\
\text { LoLEs (\%) }\end{array}$ & $(b) /(a)$ & $\begin{array}{c}1990 \\
\text { (a) Sector } \\
\text { share in } \\
\text { NVIO (\%) }\end{array}$ & $\begin{array}{l}\text { (b) Sector } \\
\text { share in } \\
\text { LoLEs (\%) }\end{array}$ & $(b) /(a)$ & $\begin{array}{c}1995 \\
\text { (a) Sector } \\
\text { share in } \\
\text { NVIO (\%) }\end{array}$ & $\begin{array}{l}\text { (b) Sector } \\
\text { share in } \\
\text { LoLEs (\%) }\end{array}$ & $(b) /(a)$ \\
\hline $\begin{array}{l}32 \text { Electrical equipment \& } \\
\text { machinery }\end{array}$ & 4.05 & 1.34 & 0.33 & 4.12 & 2.20 & 0.53 & 4.48 & 4.20 & 0.94 \\
\hline $\begin{array}{l}33 \text { Electronics \& } \\
\text { telecommunications }\end{array}$ & 2.27 & 4.57 & 2.01 & 2.87 & 2.03 & 0.71 & 4.58 & 3.84 & 0.84 \\
\hline $\begin{array}{l}35 \text { Electricity power, gas \& hot } \\
\text { water production \& supply }\end{array}$ & 4.80 & 2.94 & 0.61 & 4.77 & 3.84 & 0.81 & 5.74 & 6.82 & 1.19 \\
\hline 37 Tap water production \& supply & 0.32 & 0.28 & 0.87 & 0.28 & 0.65 & 2.34 & 0.41 & 0.57 & 1.39 \\
\hline Top 5 industries combined & & 62.95 & & & 53.32 & & & 42.79 & \\
\hline Top 10 industries combined & & 80.45 & & & 73.28 & & & 65.87 & \\
\hline
\end{tabular}

Note:

LoLEs $=$ losses of loss-making enterprises. Sources:

As Table 1. 
increases from 49 per cent in both 1986 and 1990 to 62 per cent in 1995. Looking at the values of the loss index, however, one can detect a considerable degree of disparity among the industries. On one side, there are six industries (code 20, 26, 29-30, 31, 32, 33) whose value of the loss index either persistently stays at or below the level of one - implying that the performance is at least on a par with the industry average - or falls from any higher level to below one. On another side, there are four industries (code 07-08, 09, 11, 25) whose value of the loss index either persistently exceeds one or increases from any lower level to exceed one. Given that these two groups of industries cannot be in any way identified with a clear division between SOEs and non-SOEs, one cannot infer from this disparity about the impact of ownership differences on loss-making (in 1995, whilst the net output share of SOEs in Chinese industry as a whole is 54 per cent, two of the six industries with the first group are with SOEs' share of sectoral output above 50 per cent and three of the four industries with the second group are with the share below 50 per cent; see Table 5 in the next section). What one can infer from the observation is that differences across industrial sectors largely account for the capability of enterprises, both SOEs and non-SOEs, in adjusting to cope with loss-making.

The observation and inference made above can be to some extent verified by explicitly examining the distribution of total losses incurred by SOEs and non-SOEs among different industrial sectors, which are presented in Table 4. ${ }^{9}$ To analyse the data, the industrial sectors are divided into three groups: namely, sectors where the loss share is significant for both SOEs and non-SOEs, sectors where it is significant for SOEs only, and sectors where it is significant for non-SOEs only. Sectors that fall into the first group are food processing (code 07-08), textile (11), chemicals (20), building materials (25) and machinery (2930). Sectors that fall into the second group are coal mining (code 01), petroleum extraction (02) and electricity supply (35). Sectors that can be included in the third group are plastic products (24), metal products (28), electrical equipment (32) and electronics (33).

From this classification emerges one significant point of difference between SOEs and non-SOEs: the three sectors in the second group are exactly the energy industries that belong to the planning track of China's price system in most of the 1980s, while those in the third group unambiguously belonging to the market track. For sectors in the planning track, the relative prices of their products were administratively kept low by the government before the completion of price reform in the early

9. The intention of the sector-level analysis is not to compare the relative performance of SOEs and non-SOEs - which should be done at the aggregate level, and has already been (we think) settled with respect to the analysis of Table 2. Rather, the intention is to investigate the impact of sectoral differences on loss-making of both SOEs and non-SOEs, given our prior knowledge about these differences (dual-track pricing system, demand conditions, etc.). It is for this reason that the analysis focuses only on the top ten loss-making sectors, including the energy industries. Also because of this, it does not seem to matter that we analyse the sector loss shares rather than sector output-adjusted loss indices, although it is true that a large sector loss share is often caused by a large output share. 
Table 4: Top Ten Loss-making Industries of SOEs and Non-SOEs, 1986-1991, 1995

\begin{tabular}{|c|c|c|c|c|c|c|c|c|c|c|c|c|c|c|c|}
\hline & & \multicolumn{7}{|c|}{ Sector share of losses by SOEs (\%) } & \multicolumn{7}{|c|}{ Sector share of losses by non-SOEs (\%) } \\
\hline & & 1986 & 1987 & 1998 & 1989 & 1990 & 1991 & 1995 & 1986 & 1987 & 1988 & 1989 & 1990 & 1991 & 1995 \\
\hline \multicolumn{2}{|c|}{ All industries (40 in total) } & 100.0 & 100.0 & 100.0 & 100.0 & 100.0 & 100.0 & 100.0 & 100.0 & 100.0 & 100.0 & 100.0 & 100.0 & 100.0 & 100.0 \\
\hline IND01 & $\begin{array}{l}\text { Coal mining \& } \\
\text { processing }\end{array}$ & 39.5 & 41.8 & 36.2 & 27.8 & 20.7 & 20.5 & 3.4 & & 3.1 & & & & & \\
\hline IND02 & $\begin{array}{l}\text { Petroleum \& natural } \\
\text { gas extraction }\end{array}$ & & 3.3 & 13.9 & 24.0 & 13.6 & 12.7 & & & & & & & & \\
\hline IND05 & $\begin{array}{l}\text { Building materials \& } \\
\text { other non-metal } \\
\text { minerals mining \& } \\
\text { dressing }\end{array}$ & 1.8 & & & & & & & & & & & & & \\
\hline $\begin{array}{l}\text { IND07- } \\
08\end{array}$ & $\begin{array}{l}\text { Food manufacturing } \\
\& \text { processing }\end{array}$ & 6.7 & 7.3 & 5.1 & 4.4 & 6.6 & 5.4 & 8.9 & 5.4 & 6.6 & 4.9 & 6.2 & 5.0 & 4.3 & 6.4 \\
\hline IND09 & $\begin{array}{l}\text { Beverage } \\
\text { manufacturing }\end{array}$ & & & & 2.9 & 2.7 & & & & 4.3 & 4.4 & 4.8 & 3.6 & & \\
\hline IND10 & Tobacco processing & & & 2.4 & 3.8 & & 5.2 & & & & & & & & \\
\hline IND11 & Textile & 3.5 & 3.0 & 2.1 & 2.8 & 8.0 & 10.2 & 12.7 & 12.1 & 12.7 & 13.3 & 14.7 & 17.5 & 20.0 & 11.2 \\
\hline IND12 & $\begin{array}{l}\text { Garments \& other } \\
\text { fibre products }\end{array}$ & & & & & & & & & & & & & & 4.7 \\
\hline IND19 & $\begin{array}{l}\text { Petroleum refining, } \\
\text { coking \& coal } \\
\text { products }\end{array}$ & 2.2 & 2.7 & 3.7 & 2.9 & & & & & & & & & & \\
\hline
\end{tabular}




\begin{tabular}{|c|c|c|c|c|c|c|c|c|c|c|c|c|c|c|c|}
\hline IND20 & $\begin{array}{l}\text { Raw chemical } \\
\text { materials \& } \\
\text { chemical products }\end{array}$ & 13.4 & 3.7 & 2.7 & 3.3 & 4.0 & 4.1 & 4.5 & 5.0 & 4.3 & 4.8 & 5.7 & 5.2 & 4.8 & 5.4 \\
\hline IND24 & Plastic products & & & & & & & & 4.9 & 3.6 & 3.3 & 4.2 & 4.4 & 4.7 & \\
\hline IND26 & $\begin{array}{l}\text { Ferrous metals } \\
\text { smelting \& pressing }\end{array}$ & & & & & 3.1 & 2.7 & 5.3 & & & & & 2.6 & & \\
\hline IND31 & $\begin{array}{l}\text { Transport } \\
\text { equipment }\end{array}$ & 2.5 & 3.3 & & & & & 6.3 & & & & & & & 4.8 \\
\hline IND32 & $\begin{array}{l}\text { Electrical equipment } \\
\& \text { machinery }\end{array}$ & & & & & & & & 4.1 & 5.6 & 4.6 & 4.2 & 5.7 & 7.0 & 6.0 \\
\hline IND33 & $\begin{array}{l}\text { Electronics \& } \\
\text { telecommunications }\end{array}$ & & & & & & & 3.3 & & & 2.7 & 2.5 & & 4.7 & 4.5 \\
\hline \multicolumn{2}{|c|}{ Top 5 combined share } & 73.3 & 68.4 & 70.9 & 69.0 & 59.7 & 58.5 & 48.1 & 40.8 & 47.4 & 46.5 & 49.8 & 49.5 & 46.9 & 40.1 \\
\hline
\end{tabular}

Sources:

As Table 2; and State Statistical Bureau, Zhonghua renmin gongheguo 1995 nian disanci quanguo gongye pucha ziliao huibian (Data of the Third Industrial Census of the People's Republic of China in 1995) (Beijing: Zhongguo tongji chubanshe, 1997), Vol. 2, pp. 16-168. 
1990s. Consequently, the dual-track price system and the phased price reform of the government also explain the much higher degree of sectoral concentration of losses for SOEs initially and the gradual convergence of the concentration ratio towards that of non-SOEs over time, which are clearly indicated by the figures of top five combined share of total losses in the table.

The industries in the first group, in which both SOEs and non-SOEs suffered from heavy losses, were already mainly in the market track of the price system by the late 1980s. Nevertheless, this was achieved on the basis of earlier price de-controls. In the case of chemicals, the abrupt fall of the share of total losses incurred by SOEs from 13 per cent in 1986 to 4 per cent in 1987 - thus converging to the level of non-SOEs - is a case in point. As for the machinery sector, whilst the market track has been predominant, by the late 1980s there were still segments (such as agricultural machinery, heavy machinery and military-related equipment) where SOEs were burdened by the government policy of artificially suppressing output prices. Finally, the remaining three industries of the first group have been in the market track throughout the reform era. The losses thus appear to be mainly accounted for by structural factors specific to the industries, particularly the problem of persistent excess capacity which is discussed in more detail below. In other words, this observation appears to confirm the inference made above that differences across industries, rather than across ownership sectors, account for the disparity in loss-making. Indeed, the persistence of heavy losses incurred by both SOEs and non-SOEs in these industries indicates that the industry-specific factors have simply outweighed the capability of both in adjusting to cope with the loss-making problem.

\section{Competition, Profitability Decline and Loss-Making}

The nature of the "increased competition inducing profitability decline" story is such that it focuses more on the process of change in China's enterprise development than on contrasting the various states of the process with any notional, end-state model of the economy. In other words, it takes an evolutionary approach, and, as such, it belongs to the gradualist school that rivals the big bang or shock therapy school in the broader debate over the transformation of Soviet-type economic systems. ${ }^{10}$ At the level of empirical analysis, the motivation of the story arises mainly from the finding about the general trend of convergence of profit-to-capital ratios across China's industrial sectors since the beginning of the reform. In statistical terms, the standard deviation (or coefficient of variation) of sector profit rates has tended to decrease over time. The interpretation of this trend as being caused mainly by increased

10. Russell Smyth ("New institutional economics in the post-socialist transformation," Journal of Economic Surveys, Vol.12 (1998), pp. 361-398) provides a good review of the debate. Dic Lo ("Reappraising the performance of China's state-owned industrial enterprises, 1980-96," Cambridge Journal of Economics, Vol.23 (1999), pp. 693-718) gives a more China-focused account. 
competition in Chinese industry is reinforced by the further finding that the marginal returns to productive inputs have tended to converge across sectors and economic establishments. ${ }^{11}$

Three propositions pertaining to the story clearly reflect its nature. These are, first, that China's economic reform has been characterized by the promotion of market competition, especially via the entry of nonSOEs; secondly, that this increased competition has eroded industrial profitability, both at the aggregate level and even more so in sectors where non-SOEs have been the most active; and, thirdly, over time, the pressure of competition has extended to sectors where SOEs remain predominant, thereby resulting in the convergence of rates of return to capital across different industrial sectors. ${ }^{12}$ These propositions largely contradict the "inefficient institutions causing poor financial performance" story reviewed in the preceding section. In particular, the second proposition implies that the observed profitability decline is in the main unrelated to the existence of the state sector, while the third proposition implies that China's economic reform has managed to transform SOEs into competition-responsive firms - even in sectors where the entry of non-SOEs is limited.

Irrespective of its specific propositions, compared with the ownershipcentred story the competition-centred story is on the whole more consistent with the observable fact that the levels of SOEs' profit rates have been very close to that of non-SOEs throughout the reform era. As can be seen from Figure 2, it is only in recent years, since 1992 or so, that the profit rates of SOEs have fallen below the levels of the industry average. And the gap between the profit rates of the two has been in any case very small. Thus, it would be an exaggeration to claim that the trend of secular decline of China's industrial profitability has been caused mainly by the allegedly inefficient institutions of SOEs. The fact that the profit rate of large-scale industrial enterprises, also shown in Figure 2, has persistently exceeded that of the industry average by a fairly substantial margin further contradicts the ownership-centred story. It is noted that the majority of these enterprises are in fact SOEs; in 1997, SOEs accounted for 74 per cent of the value-added of all large-scale TAIAIEs. They are the core of China's state-owned industry.

Regarding the specific propositions, the one that concerns the competition-responsiveness of SOEs is potentially very interesting but has appeared to be significantly under-studied. It is interesting because of the well-known fact that, in Chinese industry, the majority of non-SOEs have been public firms of various kinds with institutions and behaviour in

11. Naughton, Growing Out of the Plan; Raiser, "Evaluating Chinese industrial reforms"; Wang, China's Price and Enterprise Reform. G. H. Jefferson, T.G. Rawski and Y. Zheng, "Growth, efficiency, and convergence in China's state and collective industry," Economic Development and Cultural Change, Vol.40 (1992), pp.239-266.

12. Jefferson and Rawski, "How industrial reform worked"; Naughton, Growing Out of the Plan. G. H. Jefferson and I. Singh, "Ownership reform as a process of creative reduction in Chinese industry," in Joint Economic Committee of the Congress of the United States (ed.), China's Economic Future: Challenges to U.S. Policy (New York: M.E. Sharpe, 1997). 
Figure 2: Pre-Tax Profit Rates, 1980-1997

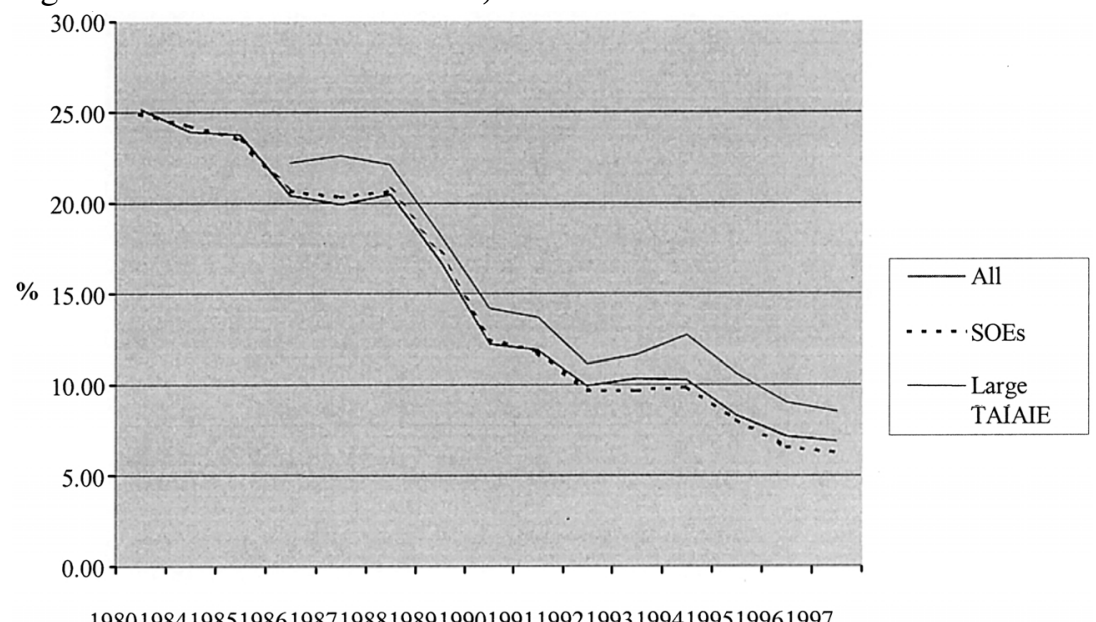

198019841985198619871988198919901991199219931994199519961997

Year

Sources:

State Statistical Bureau, Zhongguo tongji nianjian (China Statistical Yearbook) and Zhongguo tongji zhaiyao (China Statistical Abstract) (Beijing: Zhongguo tongji chubanshe), various issues.

significant measures resembling SOEs. Ascertaining the character of SOEs in this regard would generate important insights for understanding the peculiar nature of China's economic reform as a whole. But, because of the difficulty in tractability, available studies in the literature have not been very revealing. The analysis by Gary Jefferson and Thomas Rawski, for example, is typical of those studies in support of the third proposition mentioned above by relying on subjective (and thus not really definitive) indicators as measures of competition, such as each SOE's estimate of the elasticity of demand for its products or its perception of the degree of competitive pressure from rivals.

Meanwhile, studies that are critical of the proposition have also been problematic in measuring competition and its impact. A typical example is Huang and Duncan, who find that, for a panel data set of 800 SOEs in the period 1980-94, the correlation between the proportion of planned output of enterprises and the level of profit is statistically insignificant, while the correlation between the former variable and whether the enterprises are making profits is significant but negative. On this basis, the two authors claim that "the study strongly rejects the popular argument that the worsening financial performance of China's SOEs during the reform period was mainly due to increased competition." But this claim is unwarranted, because what is relevant to the competition-centred story is the sector average profit rates - or, more precisely, changes of the profit rates over time - rather than the profit levels or whether individual enterprises are making profits. The fact that, in the context of China's dual-track pricing system which existed until the early 1990s, the planned prices of output were depressed by the government and hence the relevant enterprises would tend to get more revenue from a reduction in the 
proportion of planned output, further implies that this variable could hardly serve as an indication of competition. ${ }^{13}$

It is the second proposition indicated above, concerning the correlation between the entry of non-SOEs and profitability decline at the level of individual industrial sectors, that has invited much work in the relevant literature. However, this is also a topic where the empirical findings have tended to be in conflict rather than in agreement. The conflict arises from various sources, including the different time periods examined, the levels of aggregation of industry concerned, and the statistics used for measuring the degree of presence of non-SOEs. ${ }^{14}$

Nevertheless, in the context of the analysis of the main loss-making industries listed in the previous section, there is evidence indicating that sectors with a higher degree of presence of non-SOEs do tend to have a lower profit rate. As can be seen from Table 5, for both 1990 and 1995 (where the relevant net output data are available), eight out of the ten industries appear to fit with this prediction. More precisely, the eight industries are with SOEs' output share of the sector and the sector profit rate either simultaneously exceeding or simultaneously being below the average of all industries. The exceptions are food processing (code 07-08) and electrical equipment (32) in 1990, and chemicals (20) and ferrous metals smelting (26) in 1995. Since the analysis is a cross-sectional one, it is free of the controversy over the time period to be examined. By using net output data, it also gives an indication that is more reliable than data of gross output or fixed assets about the distribution of sector-level industrial activities between SOEs and non-SOEs. Finally, although not shown in the table, it can be verified that when applying the analysis to Chinese industry as whole 27 out of a total of 37 sectors in 1995 appear to fit with the same prediction.

The figures in Table 5 also indicate an interesting phenomenon concerning the sectoral profit rates of these main loss-making industries. In 1986, only five (code 07-08, 25, 29-30, 31 and 33) out of the ten industries have profit rates lower than the average of all industries. This does not fit with the prediction of the competition-centred story concern-

13. Jefferson and Rawski, "How industrial reform worked." Y. Huang and R. Duncan, "Did competition drive down the profitability of China's state-owned enterprises?" MOCT-MOST: Economic Policy in Transitional Economies, Vol.9 (1999), pp. 49-60. Y. Huang, W.T. Woo and R. Duncan, "Understanding the decline of China's state sector," MOCT-MOST: Economic Policy in Transitional Economies, Vol.9 (1999), pp. 1-15.

14. It is well known that the Chinese economy has undergone several cycles over the reform era. The analysis of the correlation between entry and profit decline, both concerning changes over time, is thus bound to be affected by the time period covered. The measurement issue is also very difficult to resolve. Conceptually, one could use SOEs' shares of net output or value-added in individual industrial sectors to indicate the degree of presence of non-SOEs. But, as mentioned in n. 1, the relevant data for years before 1991 are not available. What are available are the gross output data which are a dubious measure for this purpose, because for years where both data series are available the net-to-gross output ratios vary very widely across different sectors. Jefferson and Singh, "Ownership reform," meanwhile, draws attention to the ambiguities concerning the economic meaning of reported measures of fixed assets in Chinese industry. Especially in view of the substantial proportion of the so-called "non-productive" component in the fixed assets of SOEs, it is not clear that the data could be used for comparing their relative degree of presence in individual industrial sectors. 
Table 5: Sectoral Profit Rates and Entry of Non-SOEs In Main Loss-Making Industries, 1986, 1990,1995

\begin{tabular}{|c|c|c|c|c|c|c|c|c|c|c|}
\hline & & \multicolumn{3}{|c|}{1986} & \multicolumn{3}{|c|}{1990} & \multicolumn{3}{|c|}{1995} \\
\hline & & $\begin{array}{c}\text { SOEs' } \\
\text { share } \\
\text { of NVIO }\end{array}$ & $\begin{array}{l}\text { Sector } \\
\text { profit } \\
\text { rate }\end{array}$ & $\begin{array}{c}\text { Incidence } \\
\text { of loss- } \\
\text { making }\end{array}$ & $\begin{array}{c}\text { SOEs' } \\
\text { share } \\
\text { of NVIO }\end{array}$ & $\begin{array}{l}\text { Sector } \\
\text { profit } \\
\text { rate }\end{array}$ & $\begin{array}{c}\text { Incidence } \\
\text { of loss- } \\
\text { making }\end{array}$ & $\begin{array}{c}\text { SOEs' } \\
\text { share } \\
\text { of NVIO }\end{array}$ & $\begin{array}{l}\text { Sector } \\
\text { profit } \\
\text { rate }\end{array}$ & $\begin{array}{c}\text { Incidence } \\
\text { of loss- } \\
\text { making }\end{array}$ \\
\hline \multicolumn{2}{|c|}{ All industries (40 industries in total) } & & 20.43 & 13.16 & 70.07 & 12.20 & 21.07 & 53.78 & 8.29 & 25.06 \\
\hline IND07-08 & Food manufacturing \& processing & & 17.84 & 13.34 & 74.70 & 9.22 & 20.38 & 43.12 & 5.70 & 23.55 \\
\hline IND09 & Beverage manufacturing & & 22.11 & 19.75 & 86.67 & 15.68 & 29.86 & 57.90 & 14.42 & 28.56 \\
\hline IND11 & Textile & & 22.44 & 15.56 & 56.65 & 9.84 & 30.33 & 36.36 & 2.52 & 33.98 \\
\hline IND20 & $\begin{array}{l}\text { Raw chemical materials \& } \\
\text { chemical products }\end{array}$ & & 20.81 & 19.76 & 75.69 & 17.41 & 23.26 & 56.41 & 8.21 & 25.61 \\
\hline IND25 & $\begin{array}{l}\text { Building materials \& other non- } \\
\text { metal mineral products }\end{array}$ & & 20.01 & 12.81 & 54.80 & 9.15 & 23.59 & 34.93 & 6.81 & 19.32 \\
\hline IND26 & Ferrous metals smelting \& pressing & & 22.25 & 14.40 & 90.94 & 16.27 & 31.82 & 77.12 & 7.38 & 30.44 \\
\hline IND29-30 & $\begin{array}{l}\text { General \& special purpose } \\
\text { machinery }\end{array}$ & & 15.96 & 9.34 & 65.83 & 6.98 & 18.81 & 44.26 & 5.91 & 24.58 \\
\hline IND31 & Transport equipment & & 11.95 & 11.62 & 66.68 & 8.64 & 17.19 & 52.22 & 7.69 & 28.28 \\
\hline IND32 & Electrical equipment \& machinery & & 27.19 & 11.54 & 51.53 & 12.74 & 19.00 & 22.76 & 6.95 & 27.17 \\
\hline IND33 & Electronics \& telecommunications & & 12.81 & 15.32 & 65.11 & 9.75 & 23.44 & 24.62 & 7.94 & 33.54 \\
\hline
\end{tabular}

Notes:

The 1995 NVIO figures are proxied by industrial value-added data, while the 1990 figures are calculated from GVIO data on the assumption that the NVIO-GVIO ratios are the same as in 1991.

Sources:

As Table 4; and State Statistical Bureau, Zhongguo gongye jingji tongji nianjian 1993 (China Industrial Economic Statistical Yearbook 1993) (Beijing: Zhongguo tongji chubanshe, 1999), pp. 142-155; State Statistical Bureau, Zhongguo tongji nianjian 1991 (China Statistical Yearbook 1991) (Beijing: Zhongguo tongji chubanshe, 1992), pp. 407, 417; State Statistical Bureau, Zhongguo tongji nianjian 1992 (China Statistical Yearbook 1992) (Beijing: Zhongguo tongji chubanshe, 1993), pp. 421, 429. 
ing the positive correlation between profitability decline and loss-making. The situation is basically unaltered by 1990, where the number of industries with profit rates lower than the aggregate rate increases to six (code 11, in addition to the previous five). By 1995, however, the number rises to nine, meaning only one (code 09) out of the ten industries is not in line with the prediction. A similar but less pronounced trend is evident regarding the correlation between sectoral profit rates and the incidence of loss-making, which according to the competition-centred story should be negative. In 1986, only three out of the ten industries fit with this prediction. The number increases to four in 1990 and six in 1995. ${ }^{15}$

The analysis above seems to suggest that there is indeed a positive correlation between profitability decline and loss-making at the sector level, but that correlation is conditional on some other factors and hence has fluctuated over time. This inference is confirmed by the trends of industrial profit rate and the incidence and scale of loss-making at the aggregate level. Looking at Figures 1 and 2, and from a long-term perspective, one can see that the trends are broadly in line with the prediction. Industrial profitability has experienced a steady decline, while the incidence and scale of loss-making have tended to increase. Divided into sub-periods of the reform era, however, the correlation between the trends disappears. For the period between 1980 and 1988, for example, whilst industrial profitability exhibits a substantial decline, the incidence and scale of loss-making do not show a clear upward trend. Likewise, for the period between 1990 and 1994, the loss rate and the profitability move in the same direction (they are both falling), whereas the incidence of loss-making shows an erratic trend. Thus, it is necessary to investigate the possible factors that condition the relationship between profitability decline and loss-making.

\section{Demand Conditions, Industrial Configurations and Loss-Making}

The competition-centred story emphasizes primarily the impact of an increase in industry supply on enterprise financial performance. The analysis, therefore, does not take into account changes in demand conditions as a factor determining the performance of both the industrial sector and the enterprises. Nor does it pay attention to the asymmetric adjustment mechanism of Chinese industry. In the 1980s, along with the

15. Note that the proposition on the relationship between the degree of presence of non-SOEs and sector profit rate, and that between sector profit rate and loss-making, both actually concern changes over time. We apply them in a cross-sectional way in order to take into account the broader context of the convergence tendency, i.e., the tendency for profit rates across sectors to converge in the general environment of market-oriented reform. In other words, under the convergence tendency, sector profit rates that initially deviated from the average would tend to converge to the average irrespective of the degree of presence of non-SOEs. What we want to investigate here, therefore, is a more specific issue: whether or not sectors that have over-done the convergence tendency (i.e., with sector profit rates falling below the average) tend to have an above-average presence of non-SOEs. Likewise, the further issue to investigate is whether or not sectors that have over-done the convergence tendency tend to have an above-average share of loss-making. 
general expansion in income of most of the Chinese population, there was a rapid growth of consumption demand which, in turn, induced a rapid expansion of investment in most manufacturing industries. Cyclical factors have affected the demand and have in turn led to fluctuations in the profitability and loss-making of Chinese industry (Figures 1 and 2). Yet, the general slow down of demand expansion in the 1990s has inevitably caused a gradual deterioration in the financial performance of China's industrial enterprises.

Conceptually, in a perfectly competitive market, the pressure of competition normally squeezes out loss-making firms, thus reducing supply and retaining an acceptable level of profitability. However, in the context of China's actual experience, whereas entry to an industry has been made easy by economic reform, exit has been difficult. Against this background, and in conjunction with the slowdown in demand expansion, excess production capacity has tended to grow over time. Thus, compared with the competition-centred story as it stands, perhaps a more reasonable and more fundamental way to show how losses of enterprises are related to the increase in market competition is to investigate the utilization rate of production capacity in Chinese industry. This index, by definition, measures how much of the production equipment invested earlier is being used to meet market demand. The lower the index, the higher the degree of competition, no matter whether it comes from SOEs or non-SOEs. The 1995 Industrial Census reports the utilization rate of production capacity for 112 industrial products. Of these, 53 match with the sub-classified industries, for which financial information can be obtained.

Simple regression analysis has been applied to investigate whether the utilization rate of production capacity explains the incidence of losses and the loss rate. As shown in Table 6, the results indicate that the utilization

Table 6: Financial Losses and Capacity Utilization - Regression Results

\begin{tabular}{|c|c|c|c|}
\hline & $\begin{array}{c}\text { Dependant variable } \\
\text { Loss incidence }\end{array}$ & Loss rate $I^{*}$ & Loss rate II \\
\hline \multicolumn{4}{|l|}{ Independent variable } \\
\hline Constant & $\begin{array}{l}38.498 \\
(10.523)^{* *}\end{array}$ & $\begin{array}{l}10.192 \\
(8.406)^{* *}\end{array}$ & $\begin{array}{l}16.729 \\
(5.369) * *\end{array}$ \\
\hline Capacity utilization rate & $\begin{array}{c}-0.166 \\
(-2.950)^{* *}\end{array}$ & $\begin{array}{l}-0.087 \\
(-4.661)^{* *}\end{array}$ & $\begin{array}{c}-0.112 \\
(-2.342)^{*}\end{array}$ \\
\hline Adjusted R-square & 0.129 & 0.265 & 0.0794 \\
\hline Number of observations & 53 & 53 & 53 \\
\hline \multicolumn{4}{|l|}{ Notes: } \\
\hline \multicolumn{4}{|c|}{$\begin{array}{l}\text { Loss incidence }=\text { percentage share of enterprises that are making losses. Loss rate } \\
1=\text { amount of losses divided by net value of fixed assets. Loss rate II }=\text { amount of losses } \\
\text { divided by net output value. Figures in parentheses are t-ratios, with * indicating } 5 \% \\
\text { significance and } * * 1 \% \text { significant. }\end{array}$} \\
\hline
\end{tabular}


Figure 3: Utilization Rate of Industrial Production Capacity and Financial Losses of Enterprises, 1995

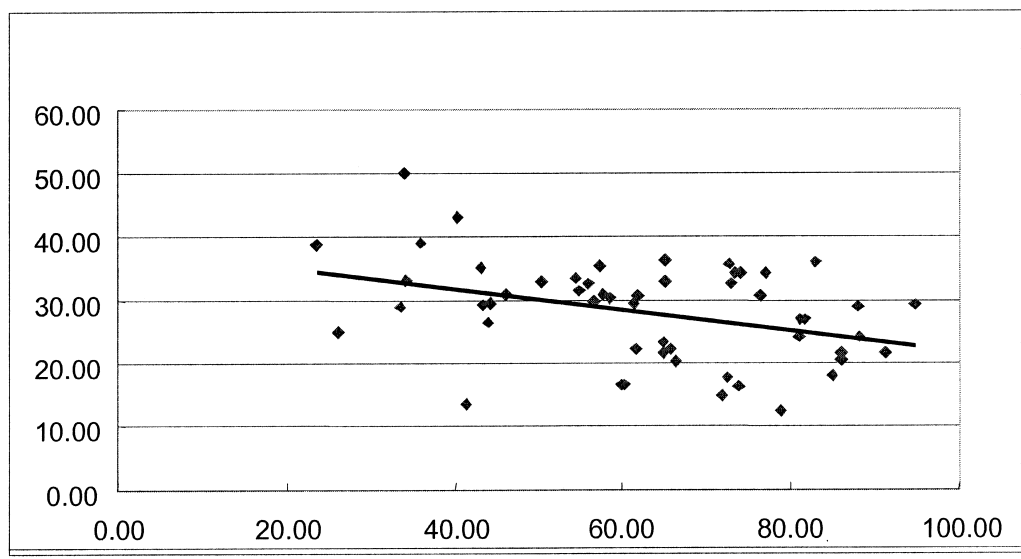

(a) Loss incidence and capacity utilisation rate.

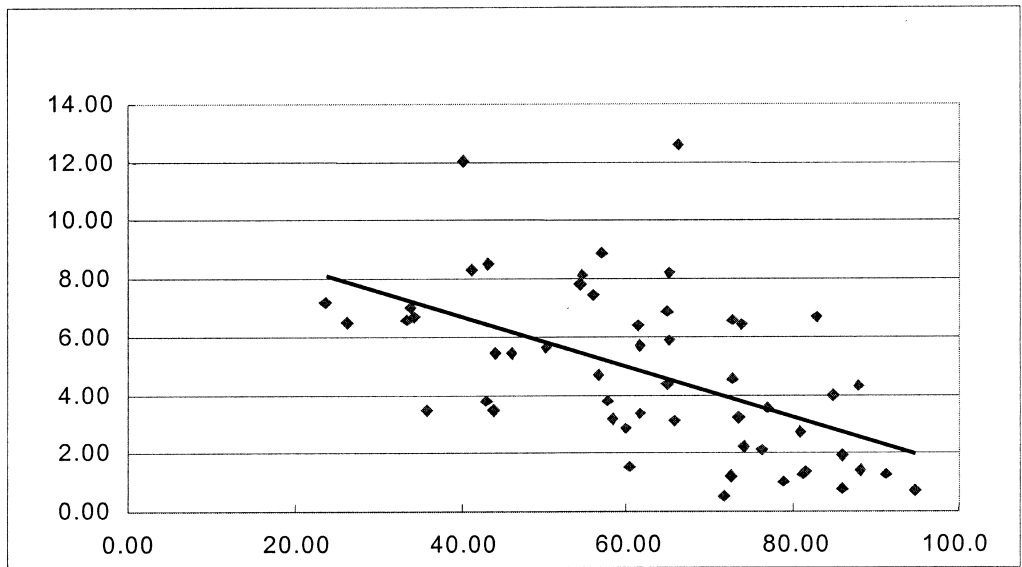

(b) Loss rate (I) and capacity utilisation rate.

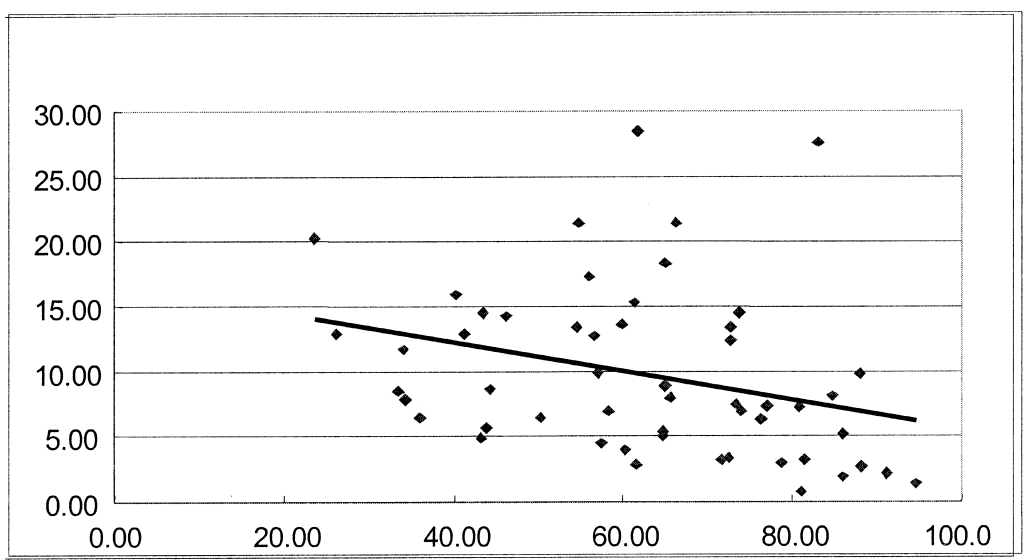

(c) Loss rate (II) and capacity utilisation rate. 
rate is very significant in all the three equations, in which the incidence of losses and two different definitions of loss rates are used as the dependent variable. The relationship can easily be seen in Figure 3, in which the utilization rate is plotted against the dependent variables used in the regressions.

But the analysis provides only a picture at the industrial sector level. There is no information, for instance, about what kind of enterprises are ascribable to the excess capacity in Chinese industry. Nor does it show whether there are winners in this generally deteriorating market situation. This question is important as it concerns the distribution of profits and losses among market players and is thus related to the nature of competition in Chinese industry. As mentioned above, a variety of sector-level studies have observed that there has been a trend of increasing market concentration in the 1990s. Large enterprises in various product markets have successfully restructured themselves and have been able to meet the challenge of growing market competition. It is thus possible that they have reaped an increasing amount (or share) of the profits, although the industry-average profit rate has been declining.

Further breakdown information of the utilization rate of production capacity is not available. Nevertheless, an investigation into the changes in the profits and losses of enterprises of different sizes over time is revealing. As shown in Table 7, in 1986, the pre-tax profit rate of large, medium and small-scale enterprises was in the ratio of 1.25: 1.26: 1.00. It changed to 1.42 : 1.22 : 1.00 in 1990 . This change implies that, during the second half of the 1980s, medium-scale enterprises were basically able to maintain their position in market competition, although the increased competitiveness of large-scale enterprises was already evident. The same ratio changed further to 1.70: 1.00: 1.00 in 1997. Clearly, large-scale enterprises established their unchallenged position in market competition in the first half of the 1990s, resulting in the convergence of the performance of medium-scale and small-scale enterprises towards the worst.

The above figures probably only reveal how good successful large enterprises are as compared to other successful enterprises. One may be interested in how loss-making large enterprises compared with other loss-making enterprises. The table shows that the loss rate (total losses of loss-making enterprises divided by net output) of large, medium and small-scale enterprises was $1.51,2.34$ and 3.18 per cent respectively in 1986. They all increased tremendously to reach the level of 8.61, 9.00 and 9.14 per cent respectively in 1990. This indicates that the impact of increased competition on loss-making was relatively even across different sizes of enterprises. However, into the 1990s, the financial performance of large enterprises has improved a lot, while that of the other two groups of enterprises deteriorated substantially, as indicated by their loss rates in 1995: 4.17, 11.13 and 11.01 per cent respectively. In other words, the loss rate of large enterprises exhibits an inverted-U shape, while those for the other two groups are basically upward sloping. This important fact may easily be masked by some indexes such as the incidence of loss-making, where large enterprises did not seem to have a clearly better performance. 
Table 7: Loss Rate and Incidence of Loss-Making by Enterprise Size, 1986-1997

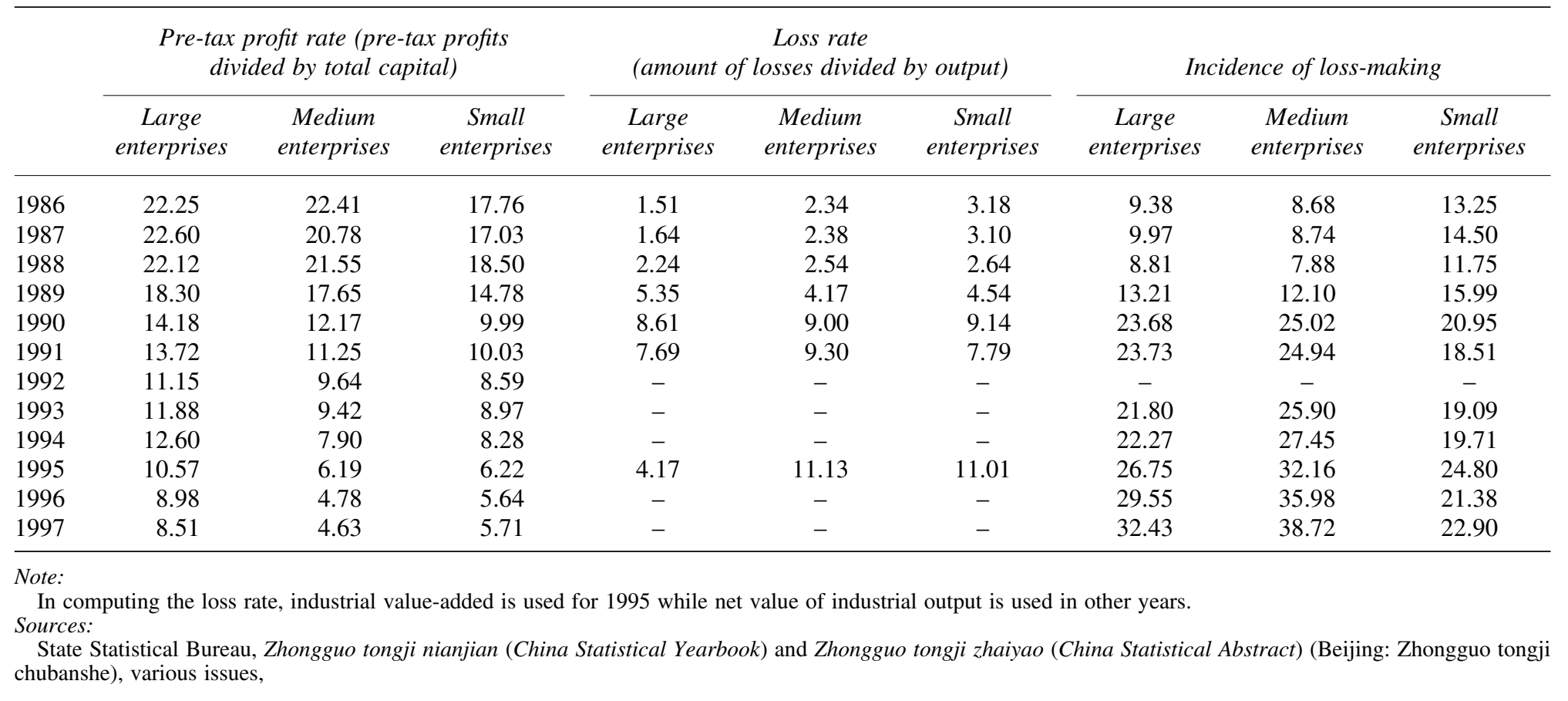


To probe further into the relationship between profitability and the industrial structure, a cross-sectional analysis has been conducted. The industrial configuration can be measured by the ratio of either the four-firm market concentration or the eight-firm market concentration, where data for 38 major industrial sectors are available for the year 1996 . As for profitability, the profit rate on assets (that is, total profits divided by the net value of assets) and the profit rate on output (that is, total profits divided by the gross industrial output value) are used. The regression results, as shown in Table 8, indicate that whichever indicator is used for profitability and for market configuration, the coefficient of concentration ratio is highly significant. Industries having a higher concentration ratio tend to have a higher profitability as well.

Such a picture indicates that the nature of competition in Chinese industry is very different from that described by the standard neoclassical model of perfect competition, under which small and identical firms are induced by economic profits to enter and exit the market. Rather, in China, the force of market competition has led to a change in the market structure and a corresponding redistribution of profits and losses among enterprises. During such a process, a number of large enterprises have survived as the winners. Indeed, in several product markets that have experienced acute competition, the market concentration has become very high. In 1997, the market share of the top ten brand names was 91.3 per cent for washing machines, 80.5 per cent for colour television sets, 91.6 per cent for refrigerators and 81.5 per cent for VCD-players. ${ }^{16}$ In these markets, competition is likely to have been oligopolistic in nature. How the mode of competition will evolve in the future depends on the strategy of enterprises as well as the government's competition policy.

\section{Conclusions}

Three findings from the preceding empirical analyses are of note: first, that the financial performance of SOEs has been quite close to the rest of Chinese industry over the reform era; secondly, that, at the sector level, there does exist a negative correlation between the degree of presence of non-SOEs and profit rate; and, thirdly, there also exists a negative correlation between sector profit rate and loss-making, but this has been conditioned by the additional factors of demand expansion and industrial configurations. These findings clearly have their implications for the main explanations offered by the literature on the declining financial performance of Chinese industry. The first finding provides the basis for rejecting the ownership-centred story as it stands, while the remaining two imply that the competition-centred story contains more elements of truth but is inadequate.

The analysis also bears policy significance. In view of the slow-down in the growth of final consumption demand in recent years, the usual policy conclusion of the ownership-centred story for cutting labour cost 
Table 8: Profitability and Industrial Configuration - Regression Results, 1996

\begin{tabular}{|c|c|c|c|c|c|}
\hline & \multicolumn{2}{|c|}{ Dependent variable } & & \multicolumn{2}{|c|}{ Dependent variable } \\
\hline & Profit rate (1) & Profit rate (2) & & Profit rate (1) & Profit rate (2) \\
\hline $\begin{array}{l}\text { Independent } \\
\text { variable }\end{array}$ & & & $\begin{array}{l}\text { Independent } \\
\text { variable }\end{array}$ & & \\
\hline Constant & $\begin{array}{c}0.914 \\
(0.424)\end{array}$ & $\begin{array}{c}2.188 \\
(1.019)\end{array}$ & Constant & $\begin{array}{c}0.453 \\
(0.200)\end{array}$ & $\begin{array}{c}1.626 \\
(0.723)\end{array}$ \\
\hline $\mathrm{C} 4$ & $\begin{array}{l}0.384 \\
(2.864)^{* *}\end{array}$ & $\begin{array}{l}0.434 \\
(3.244)^{* *}\end{array}$ & $\mathrm{C} 8$ & $\begin{array}{l}0.296 \\
(2.879) * *\end{array}$ & $\begin{array}{c}0.337 \\
(3.295)^{* *}\end{array}$ \\
\hline $\begin{array}{l}\text { Adjusted R- } \\
\text { square }\end{array}$ & 0.163 & 0.205 & & 0.165 & 0.210 \\
\hline $\begin{array}{l}\text { Number of } \\
\text { observations }\end{array}$ & 38 & 38 & & 38 & 38 \\
\hline
\end{tabular}


- by means of marketizing the employment system and relying on unemployment as a labour disciplining device - is found to be misleading in an intellectual sense and dangerous in a practical one. This will probably further dampen the growth in consumption demand, and thereby further increase the loss of enterprises. In other words, it will produce a vicious circle that is difficult to get out of. In the meantime, the usual policy conclusion of the competition-centred story for increasing market competition under whatever circumstances is also found to be wanting, because it tends to overlook the negative impact of the associated profitability decline on long-term economic development. The logical conclusion from our own analysis is that, when designing appropriate policy to deal with the loss-making phenomenon, due account needs to be taken of the changes in industrial configurations at the micro level and the slowdown of demand expansion at the macro level. 